\title{
On the mystique of numbers and the music of geometric figures as a basis for the process of the author's composition
}

Ioan POP*

Abstract: The work returns to a longstanding preoccupation of the author with the world of numbers and also very briefly in that of geometric figures. In summary, these, both numbers and figures, are placed in relation to the act of composition, in other words, the way in which these can be the basis for the creation of a specific musical discourse. After reviewing the works previously composed, namely " $O$ " and " $\triangle$ ", the research continueswith a glanceat the act of composition of the piece $" \square$ "for soprano, trombone, piano and percussion, a piece in progress at the time of writing this article, in which, alongside the symbolism of the figure four and the square, we also consider the ten sephiroth of the Kabbala, which will be represented first graphically, and then, through the medium of graphics, implicitly musically.

Keywords: number, geometric figure, circle, triangle, square, programmatic music.

"Not only pagan priests, but also Hebrew and Christian theologians, affirm in unison that the numbers, which belong in the first place to the mathematicians, being purely formal, also possess the most powerful influence acting on good and evil" (Cornelius Agrippa) ${ }^{1}$.

${ }^{*}$ PhD, Assosiate Professor, Gheorghe Dima Academy of Music, Cluj-Napoca, Romania; e-mail: popionica@yahoo.com.

${ }^{1}$ The quotation is taken from Eugen BINDEL, Mistica numerelor (Mysticism of numbers), Bucharest, Herald Publishing House, 2008, p. 25. 


\section{Introduction}

The mind strives to penetrate through and among the eternal truths with reticence and humility, driven by the attempt to find hidden links between all and everything. In this sense, speaking theoretically, the act of creation, from the human perspective, can be based on, apart from inspiration, practically any human domain ${ }^{2}$. The 20th century, especially the second half, brought an unprecedented phenomenon to the arts, especially to music. The construction and creation of music on extra-musical and experimental bases, namely physics, mathematics, geometry, elements of symbolic logic, extraction of musical essences from graphics, exotic landscapes and cultures, strings, logarithms ... and the list could continue. AurelStroie, one of the most brilliant representatives of the Romanian composition school of the twentieth century, said at the beginning of the 21 st century, in the context of what happened from the point of view of spiritualartistic interactions, that music expresses ideas. In his turn, Stroie would use in music, classes of composition borrowed from mathematics, superimpositions of systems of tuning, clouds of melodies ("multimobiles"), etc., a multitude of extra-musical elements but emotionally processed in such a way that the result would have sensitivity and sonic sense.

\section{Programmatic music}

Before talking about numbers and their meanings, so rich and sometimes contradictory, or even opposed from one people or thinker to another, let us see some connections between music and other arts, especially between music and literature, and between music and the poetry that would give birth to the

${ }^{2}$ By this we understand the totality of the modes of manifestation of human spiritual activities. 
celebrated expression of programmatic music, mainly formulated during the Romantic period. By programmatic music, we usually understand a musical piece that sounds like a story or a play, randomness, autobiographical elements, plastic images, etc. Although some musicians, especially composers, claim that music, especially the instrumental, is its own expression, many voices, especially from the uninitiated audience, assert the need for a guide, an extra-musical aid to facilitate the audience's penetration into the musical universe of classical music, especially the modern one.

"How do you listen to programmatic music? Do you have to keep the story in mind? Can you ignore the story and listen only to the music? Aestheticians have been discussing this topic for over a century and a half. Incidentally for Fantastica, Berlioz used a music that he had previously composed for other purposes and had nothing in common with the program of Fantastica"3.

First of all, if we regard the beginnings of music, we can see that music has a purpose, a practical goal, a well-defined function. Making common cause with poetry, literary text and dance, what today we call syncretism, it was part of a whole where the components could not be separated. Subsequently, the arts separated, and the program, which was mainly discussed in the post-classical but existing stage of some previous composers, does not always very explicitly provide, according to more or less informed opinions, only an access path, which for some is necessary. Just as some people see music through colours (we refer here to synaesthesia), so others need a story, an anecdote to decipher, to understand music, especially the most complicated. However, composers can juggle with their music, such as Berlioz, using self-reference, re-iterations, reinterpretations, re-use of

3 Harold SCHONBERG, Viețile marilor compozitori (The lives of great composers), Bucharest, Lieder Publishing House, 2008, p. 149. 
older fragments, whether or not changed, for other works that will become new music.

"Also, if analyzed independently of the program, Fantastica remains in many respects an orthodox symphony, with a sonorous allegro, an adagio, a scherzo and a final. Then, what is programmatic music? The answer is not easy to give. Every man listens to music in his own way. The less sophisticated listener often needs help and is tempted to "see" images in any kind of music. The professional listens differently, focusing on shape, on line, and most often completely ignoring the program" 4 .

The mode of perception and reception is almost identical in any art. The specialist observes details that the viewer or the audience of the line does not see or hear. The specialist is careful about the accuracy of the dramatic act, the quality of the interpretation, the segments of the form, which permanently places it in both the scene and the observer, critically. Usually, professional musicians enter directly into the intrinsic musical subsense due to the accumulated experience. They listen to themes built through certain melodic and rhythmic connections, with a more or less traditional timbral clothing, which increases the nuance of drama and contrast. For the ordinary man, none of thisexists. Often, he needs a thread to lead him through the labyrinth of sounds.

"On the other hand, no music can concretely describe anything. Anyone who listens for the first time to the Fantastic Symphony - or Liszt's Preludes, or Till Eulenspiegel of Strauss or Debussy's Sea - without knowing the superimposed literary text, will find it impossible to decipher the program. At best, music can express emotions and states of mind [...] A program can provide a general idea of the composer's intentions, but music succeeds or fails in purely musical terms, and this is true even for

\footnotetext{
${ }^{4}$ Ibidem, p. 149.
} 
the opera, where extra-musical associations necessarily play a role. No work has remained in the repertoire only for the qualities of the libretto. It remains because the music is great" .

It is difficult to give a verdict. The composer certainly thinks entirely in musical terms in respect of all the parameters, to the last detail. The emotions and moods of music can illustrate the program, but they usually bring something extra. The colours of sound and the warmth of interpretation. After all, everyone understands from this world what he can. Music is no exception. Àchacunsavérité. Understanding and receiving music depends on the degree of sensitivity, finesse, but also on education and intelligence, as well as the direct way in which we choose to understand music through itself or through other elements of artistic resonance.

If we can discuss a music based on a literary program, what can we say about a musical creation based on number and geometric figure? We shall see.

\section{On numbers and their mystique}

The preoccupation with numbers and their meaning has existed probably from the beginning of civilization, and especially for the numbers up to ten. We will not make an exhaustive study of this issue. The subject is vast and contradictory. The same number is beneficial for one author or people and bad for others. We shall just point out some details that we have encountered during the documentation. We start by drawing (but in reverse order) from Martin Rees' book, Only Six Numbers / the fundamental forces which model the universe. Here is what the author says at the outset.

${ }^{5}$ Ibidem, p. 149-150. 
"This book describes six numbers that now seem to be particularly significant. Two of them refer to the fundamental forces; two set the size and general structure of our universe and state whether it will continue to exist forever; and the other two characterize the properties of space itself"6.

For a musician, and not only for a musician, the search for understanding of these numbers is difficult, as is their transposition into the musical universe. They are as follows:

First $\mathbf{N}$, a very large number representing the ratio of the electric forces that hold atoms together and the gravitational force between them. If $\mathbf{N}$ was smaller, the universe would have existed only in miniature, with a very short lifetime. The value of $\mathbf{N}$ is 1 000000000000000000000000000000000000 .

The number that shows how atoms were formed on the earth and the strength of the bonds between their nuclei is $\Sigma$, with a value of 0.007 . This reminds us of the obsession of antiquity with the number 7 . "Its value is regulated by the energy sent by the Sun, and more precisely, how the transmutation of primitive hydrogen in the stars occurs in all the atoms of the periodic table" 7 (not by chance, we have the footnote with number 7).

The energy of expansion in the universe and the relative importance of gravity are indicated by the number $\boldsymbol{\Omega}$, which measures the quantity of matter of the universe - rarefied gas, galaxies, "dark matter". A much lower value of $\boldsymbol{\Omega}$ would not have allowed the formation of stars and galaxies, and a much greater value than a particular "critical" value would have led to the collapse of the universe long ago.

${ }^{6}$ Martin REES, Doar șase numere / Forțele fundamentale care modelează universal (Only six numbers / The fundamental forces shaping the universe), Bucharest, Humanitas Publishing House, 2000, p. 9-10.

${ }^{7}$ Ibidem, p. 10. 
The slowing or acceleration of the expansion of the universe (the number $\lambda$ ) is due to cosmic "antigravity" with effects that are visible only on a scale less than a few billion light years. "Fortunately for us (and to the surprise of the theorists), $\lambda$ is a very small number. Otherwise, its effect would have stopped the formation of galaxies and stars, and cosmic evolution would have been blocked just before it began" ${ }^{8}$. The use of $\lambda$ (lambda) is due to Einstein who discovered that since the bodies in a universe created in a static state attract each other, this (the universe) will begin to contract. If gravity were not offset by another force, it would prevent the universe staying in a stable state. Einstein called this number, "the cosmological constant".

"The clearest structures in the universe - stars, galaxies and galaxy swarms - are all kept together because of gravity. We can express how closely they are connected - or, equally, how much energy is needed to break them and disperse them - by a fraction of their total "resting" energy $\left(\mathrm{mc}^{2}\right)$. For the largest structures in the universe - swarms and super-swarms of galaxies - the fraction is one in one hundred thousand [1/100,000]. This is a pure number - the ratio of two energies - which we denote by $\mathbf{Q}^{9}$. "This shows us that in galaxies and swarms, gravity is very weak. Because of $\mathbf{Q}$, the universe is not inert and has a structure, not dominated, as would happen if $\mathbf{Q}$ were larger, by black holes that would prevent the survival of stars and solar systems.

The sixth number, $\mathbf{D}$, is the number of spatial dimensions of our world and is equal to three. The fourth dimension, time, which is different from the others, is a one-way arrow. But close to the black holes, time stays in place and light, due to the distortion of space, propagates in a circle. Close to our limit of understanding is that at a microscopic scale and near the moment

\footnotetext{
${ }^{8}$ Ibidem, p. 11.

${ }^{9}$ Ibidem, p. 142.
} 
of the Big Bang, space can reveal its profound universal structure: "vibrations and harmonics of objects called "strings"in a space of ten dimensions" 10 .

We leave to the scientists the task of seeing whether or not there are links between these numbers. Thanks to them we exist, which creates, at least for me, a slight state of mysticism with teleological nuances. We can now return to our flock, the first ten numbers and their combinations. Without reference to the monad, the diad, the triad, up to the decad, which you can easily find in the book of Iamblichos ${ }^{11}$, we mention only the Pythagorictetraktys as a reflection of the number one, in contemporary language a model of refraction of a single triangle:

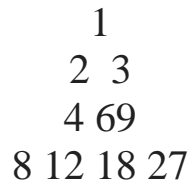

where it is easy to see, on the left and right oblique sides, the principle of two and three times, like the transition from 2 to the square 4 and the cube 8 ; and on the opposite side 3 to the square 9 and the cube $27^{12}$. Also the number 6 as a multiple of 3, and 12 as a multiple of 6 , and in the reverse sense, 6 as three times 2 and 18 as three times 6 .

\section{The numbers in The Book of Revelation according to John}

The presence of numbers in the text of Revelation to John is almost painful, full of depth and drama, referring mainly to the

${ }^{10}$ Ibidem, p. 12.

${ }^{11}$ IAmbliCHOS, Teologia aritmeticii / Despre Simbolismul Mistic, Matematic și

Cosmologic al primelor zece numere (The Arithmetic Theology / About the Mystical, Mathematical and Cosmic Symbolism of the Top Ten Numbers),

Bucharest, Herald Publishing House, 2006.

12 Ibidem, pp. 16-17. 
numbers seven (the most important and the most often mentioned), three (as the third part, a third of a third part, and so on), two (two wings of the eagle with the help of which the woman flies in the desert), four (angels, horns of the altar, hourday-month-year), five (the number of months in which the locusts assail the people ), twelve (stars, of which the woman's crown is made), ten (the horns of the beast), twenty-four (the elders standing before God on their thrones), six hundred sixty-six (the number of the beast) and a hundred forty-four thousand (the number of believers who sit with the Lamb of God. A string that starts in steps $(2,3,4,5,6,7)$ expanding through 10, 12, 24 (double of 12th), 49 (the seventh sequence that launches the seven angels with trumpets, so 7 times 7) for a jump to 666, 1260 and then 144,000 with reference points the numbers 7 and 3 . In total, 146,048 divided by 7 , gives 20.8644, the value of each angel (in order, 02468). For each part of the seventh part $(20,864)$ one third of what is or what is left of what it was is about to be destroyed. We symbolically divide 20,864 to 3 , and we get $6,954.666666666667$, a possible figure of the apocalypse. In turn, this figure divided by 3 gives 2,318.222222222222, and after a new division by 3 , we get 772.7407407407407 . Following the fourth division by 3, we get the figure 257.5802469135802, which contains all the numbers. The figures 85.86008230452675 and 28.62002743484225 and finally 9.540009144947417 correspond respectively to the final divisions by 3 , thus completing the number of seven divisions.

"8.1. When the seventh seal of the Lamb broke, a silence of almost half an hour was made in heaven. 2. And I saw the seven angels standing before God; and they were given seven trumpets. [...] 7. The first angel sounded the trumpet. And there came hail and fire mingled with blood, which were cast into the earth; and the third part of the earth was burned, and the third part of the trees were burned, and all the green grass was burnt. 8. The 
second angel sounded the trumpet. and something like a great mountain of burning fire was thrown into the sea; and the third part of the sea became blood; 9. And the third part of the beings that were in the sea, and had life, died: and the third part of the ships have perished. 10. The third angel sounded the trumpet. And a great star fell from heaven, burning like a lamp; fell over the third part of the rivers and over the water springs. [...] 12. The fourth angel sounded the trumpet. And the third part of the sun was struck, and the third part of the moon, and the third part of the stars, so that the third part of it was dark, and the third day of her light was lost, and the night also"13.

The visual projections are cinematic, with the adjacent sound background suggested. First, the earth (the third part) is hit with hail and fire, affecting the trees and all the green grass. Then the sea, the creatures of it and the third of the ships, followed by rivers and water springs. The fourth angel causes the destruction of a third of the sun, moon, and stars to diminish the light of day and night. We have hitherto assailed the earth, the water, the sun (fire as hot light) and the moon (cold light). We can interpret everything as the alchemical transformation by destroying water, fire (sun), earth and ether (moon). What follows is the injury to mankind.

The fifth angel provokes through the sound of his trumpet the fall of a star that opens the fountain of the deep from which the smoke comes out, and from it the locusts to torment people (those who have not had the seal of God on their foreheads) for five months.

"9. 13. The sixth angel sounded the trumpet. And I heard a voice out of the four horns of the golden altar that is before God. 14. And said the sixth angel who had the trumpet: "Separate the four angels who are bound to the great river Euphrates!" 15. And the four angels, who were ready for that hour, day, month, and

${ }^{13}$ Biblia sau Sfinta Scriptură a Vechiului și Noului Testament, The Bible League Sharing God's Word Since 1938, no edition, no year, p. 1211-1212. 
year, were loosed to kill the third part of the people. 16. Their army was twenty thousand times ten thousand horsemen; I heard their number. [...] 18. A third of the men were killed by these three plagues: fire, smoke, and brimstone that came out of their mouths"14.

The trumpet sound of the seventh angel triggers events of a cosmic nature: a sun-shaded woman with a twelve-star crown on her head and the moon under her feet runs away (pursued by a red dragon with seven heads and ten horns) with the help of two eagle wings in the wilderness where one thousand two hundred will be fed for sixty days; in the sky there is a war between Michael and his angels against the dragon with his angels. Also mentioned are the number of the beast (six hundred and sixty-six) and the number of those standing with the Lamb of God on Mount Zion, written on his forehead, and the name of his father (one hundred and forty-four thousand) ${ }^{15}$.

\section{Musical structure, number and geometric figure. The circle and the triangle}

We have shown in a previous study that it is interesting to note the "link that can be established between the number and the geometric figure. By extension we will then pursue the way in which the communication between the number and the geometric figure can be imagined in such a way that by their merging, filtered through the symbolism that emerges from this intersection, we will come to a transposition into a musical structure"16. The easiest way to observe this is if we first look at

${ }^{14}$ Ibidem, p. 1212.

${ }^{15}$ Ibidem, vezi p. 1212-1215.

${ }^{16}$ Ioan POP, Applications of numbers and geometrical figures in music in relation to the musical works"०", " $\Delta$ ", "口", în IFCC 2011, Proceedings of 
Figure 1 at the end of this article, which is the general scheme of the piece " $\Delta$ " (written for two sopranos, trombone and percussion), then example 2 , which is an extract from figure 1 , in the bold square, and finally we come to example 3, which actually constitutesa fragment of the work piece ${ }^{17}$. Also in example 1, we will schematically see a fragment of the "०" piece for trombone and percussion, where all the percussion instruments are arranged grouped in circles around the trombone, the percussionist having to move quickly from a tool group to another. In "○", the starting point in writing music is the significance of the zero figure and the related geometric figures: circle, sphere, ellipse, even egg, alpha and omega as attributes of divinity, etc., all of which have rich connotations, from magic to the daily. The play is thought of as the birth (cosmogony) of a universe, both physically and as a musical universe. The ideas of Romulus Vulcănescu's Romanian Mythology were of great help, especially those related to the birth of the world from the conflict between friend and fiend ${ }^{18}$. From the point of view of sounds, the first sound fa\# appears, followed by do (thesis and antithesis), then mi. There follows si, associated in chromatic scale with do and fa\#, so that finally re\# will also appear.

As for the " $\Delta$ " piece, here the starting point is the symbolism of the number three and the triangle, knowingly bypassing the Christian symbols, moving towards alchemy.

Thus we will have, along with many others, the three alchemical elements: salt, sulfur, mercury, and here is the fact that for each of the four elements: water, fire, earth, air (which the

the 2011 3rd International Conference on Future Computer and Communication, New York, Editura Asme Press, 2011, p. 430.

${ }^{17}$ Ibidem, p. 433, (examples and figures, whch appear identical also in this article).

18 Romulus VulCănescu, Mitologie Română ( Romanian mythology), Bucharest, The Publishing House of Academy R. S. R., 1985, p. 343. 
piece " $\square$ " already predicts through the symbolism of the number four), a different sonority is imagined. A straight sound, round in $\mathrm{mf}$ for the ground, a sound with vibrato for water, pointillist elements for air, and glissando combined with vibrato and eventually trill, all in forte, for fire.

Just as every number can be considered as a universe in itself, so "geometric figures and numbers can also be considered as archetypes from which continually spring forth meanings, which we can perceive only as an echo of a high spiritual plan.

Regarding the number-geometric figure link, we believe that these two determine each other as a junction between the object and its shadow"19.

\section{The meanings of the square and the number four. The ten Sephiroth}

The symbolism of the number four and implicitly of the square is rich and contradictory. From the cardinal points to the shape of the human body, from the prehistoric temples to the Christian symbol (and not only) of the cross, the square is loaded with magic, used in alchemy and astrology. We retain as significance in what interests us, the four gates that the adept of mystical life must pass, as well as the four letters that give us one of the names of God: YHWH, where we have for Y the man, for $\mathrm{H}$ the lion, for $\mathrm{W}$ the bull and for $\mathrm{H}$ the eagle, which leads us to the four evangelists. ${ }^{20}$ Starting from this name, we come to the ten sephirot, which are the instruments (kelim) by which God created the world, the channels (cinnorot) of transmission of His

${ }^{19}$ Ibidem, p. 430.

${ }^{20}$ See BoncompagnI, Solas, Lumea simbolurilor: numere, litere şi figuri geometrice (World of symbols: numbers, letters and geometric figures), Bucharest, Humanitas Publishing House, 2004, p. 61 and following. 
actions. $^{21}$ We can see in Figure 2 how the ten sephiroth are imagined as concentric squares placed on a giant musical portrait of sixteen lines (four times four) where the key of fa is on the sixth line from the bottom and the key of so the tenth. The vertical lines are also number sixteen, each being able to delimit a measure, a beat or part of a beat. The work of composition is just beginning, the squares of the sephiroth being just the starting points which initiate the future surprise.

\section{References}

1. Biblia sau Sfinta Scriptură a Vechiului și Noului Testament, The Bible League Sharing God's Word Since 1938, Ed., Year.

2. BINDEL, Eugen, Mistica numerelor (Mysticism of numbers), Bucharest, Herald Publishing House, 2008.

3. BONCOMPAGNI, Solas, Lumea simbolurilor: numere, litere şi figuri geometrice (World of symbols: numbers, letters and geometric figures), Bucharest, Humanitas Publishing House, 2004.

4. IAMBLICHOS, Teologia aritmeticii (Arithmetic theology), Bucharest, Herald Publishing House, 2006.

5. PAPUS, Kabbala, Bucharest, Herald Publishing House, 2008.

6. PoP, John (Ionica), Muzica şi geometria ( Music and geometry), Intermezzo magazine, Cluj-Napoca, MediaMusica Publishing House, December 2008, year I, no. 2.

7. PoP, Ioan (Ionica), Muzica şi geometria (II) “○” (Music and geometry 2) in Intermezzo magazine, MediaMusica, ClujNapoca, March 2009, year I, no. 3.

8. PoP Ioan, Applications of numbers and geometrical figures in music in relation to the musical works " $\circ$ ", " $\Delta$ ", " $\square$ ", in IFCC 2011, Proceedings of the 2011 3rd International Conference on Future Computer and Communication, Asme Press, New York, 2011.

${ }^{21}$ PAPUS, Kabbala, Bucharest, Herald Publishing House, 2008. 
9. REES, Martin, Only Six Numbers / The Fundamental Forces Which Model the Universe, Bucharest, Humanitas Publishing House, 2000.

10. SCHONBERG, Harold, Viețile marilor compozitori (The lives of great composers), Bucharest, Lieder Publishing House, 2008.

11. Vulcănescu, Romulus, Mitologie Română ( Romanian mythology), Bucharest, The Publishing House of Academy R. S. R., 1985. 
Example 1: extract from "O", piece for trombone and percussion

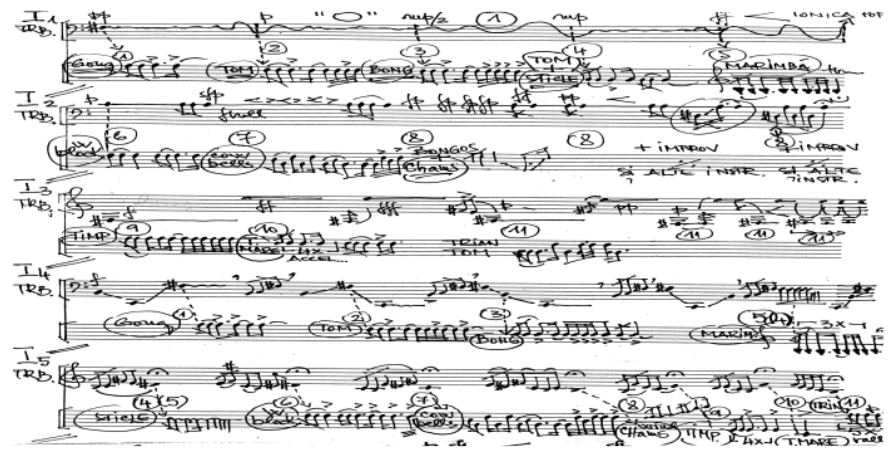

Example 2: extract from a sketch for " $\Delta$ ", piece for two sopranos, trombone and percussion
Example 3: extract from the score for the piece " $\Delta$ "
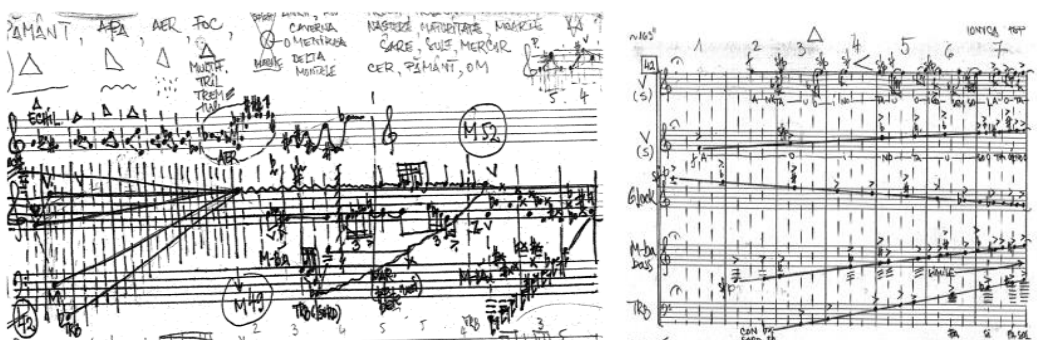

Fig. 1: sketch for " $\Delta$ "

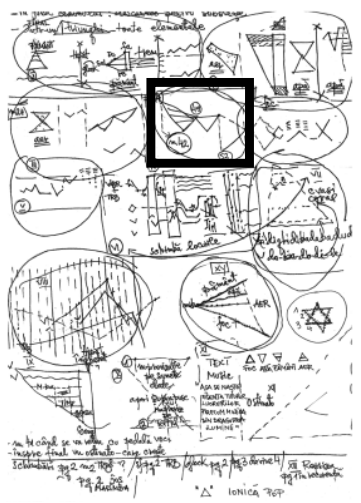

Fig. 2: sketch for "๑"

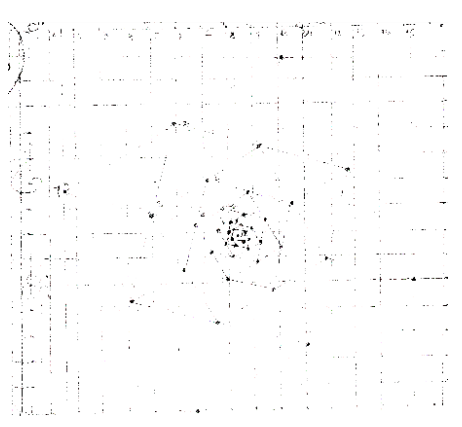

